\title{
FORMATION OF MECHANISMS OF DEVELOPMENT \\ OF FOREIGN ECONOMIC ACTIVITY \\ OF INDUSTRIAL ENTERPRISES
}

\section{ФОРМУВАННЯ МЕХАНІЗМІВ РОЗВИТКУ \\ ЗОВНІШНЬОЕКОНОМІЧНОЇ ДІЯЛЬНОСТІ \\ ПРОМИСЛОВИХ ПІДПРИЕМСТВ}

\section{Krasilych Iryna ${ }^{1}$ \\ Terebuh Andriy ${ }^{2}$}

DOI: https://doi.org/10.30525/978-9934-571-78-7_10

Abstract. The subject of the study is the mechanisms of development of foreign economic activity of industrial enterprises. The purpose of its execution was to reveal the essence of the types of mechanisms for the development of foreign economic activity of industrial enterprises, to specify the technology of forming the mechanism of development of foreign economic activity of industrial enterprises. Methodology. The development of the national economy of Ukraine in the context of deepening European integration requires radical changes in the management of foreign economic activity at macro and micro levels. Over the past two decades, there has been a steady trend towards exceeding exports over exports. The share of hightech exports is very low and geographically concentrated. The high level of energy intensity of production and the deterioration of the main production assets are the main reasons for the no competitiveness of domestic industrial products in comparison with analogues of foreign production. The generalization of analytical data of industrial enterprises suggests that the best positions on the market are those organizations that, importing modern technologies and materials, gain access to foreign markets for industrial products. For such organizations, deepening the specialization of production, geographical and product diversification are the most common tools for achieving a high level of competitiveness. Critical analysis

\footnotetext{
${ }^{1}$ Candidate of Economic Sciences, Assistant Lecturer of Department of Business Economics and Investment, National University «Lviv Polytechnic», Ukraine

${ }^{2}$ Doctor of Economics, Professor,

National University «Lviv Polytechnic», Ukraine

(C) Krasilych Iryna, Terebuh Andriy
} 
of empirical data and materials of scientists showed that the problem of strengthening the competitive positions of industrial enterprises, to a large extent, is fragmentation, unsystematic development of theoretical and methodological and applied provisions to ensure the development of foreign economic activity of enterprises. Empirical and expert data of the leaders of industrial enterprises suggest that the development of foreign economic activity is based on the use of procedural-sequential, process-parallel or combined mechanisms. The feasibility of using each of the mechanisms depends on the level of development of the enterprise management system and the existing experience of implementing foreign economic operations under different vectors. It is proved that the mechanisms of development of foreign economic activity can be constructed as a conglomerate or system. The analysis of the mechanisms of development of foreign economic activity, which are used by domestic industrial enterprises, showed that they are at best conglomerate formations. Mechanisms formed as systems are practically absent. The conducted studies suggest that the main reasons for this are the low level of development of theoretical and methodological and applied provisions on the formation of such mechanisms, as well as the superficial vocational training of managers of enterprises that manage foreign economic activity, as evidenced by the incompleteness and untimely implementation of established operational, tactical and strategic goals for the development of foreign economic activity. Conclusions. Mechanisms of development of foreign economic activity are formed in the context of certain vectors (types of foreign economic activity), the choice of which depends on the specialization of the enterprise, the type of products, its competitiveness, the existence of relations with foreign counterparties, market conditions, etc. The signs of selecting of one or more of these vectors is the presence of time-and parameterized parameters of the development of foreign economic activity of the enterprise, as well as management decisions aimed at their achievement. Given the identified features under the mechanism of development of foreign economic activity of the enterprise it is advisable to understand the set of management decisions and the conditions for their implementation, which, under the influence of managerial initiatives of enterprise managers, make it possible to achieve the goals of development of foreign economic activity on the basis of ensuring the competitiveness of the enterprise's products. 


\section{Chapter «Economic sciences»}

\section{1. Вступ}

Для прийняття керівниками підприємств раціональних управлінських рішень щодо реалізації встановлених цілей, пов'язаних із забезпеченням конкурентоспроможності підприємства необхідним $є$ застосування певної технології формування механізму розвитком зовнішньоекономічної діяльності. На основі застосування системи аксіом Цермело-Френкеля можливо виділити етапи цього технологічного процесу та аргументувати необхідність їх дотримання із урахуванням тих обставин, які є визначальними при виборі векторів і цілей розвитку зовнішньоекономічної діяльності. На основі емпіричних даних слід довести, що зміни, які відбуваються у внутрішньому і зовнішньому середовищах підприємств вимагають перманентного моніторингу. Інформативність моніторингу - важлива умова раціональності управління розвитком експортно-імпортною діяльністю. Доцільним є розкриття сутності положень з формування інформаційного забезпечення моніторингу механізму розвитку зовнішньоекономічної діяльності на основі застосування симплекс і D-оптимального планування. Це дозволить керівникам підприємств адекватно оцінювати ринкові тенденції, своєчасно встановлювати необхідність реалізації організаційних змін, обгрунтовано приймати управлінські рішення, які забезпечуватимуть конкурентоспроможність підприємства. Виявлення залежностей між результативними і факторними ознаками розвитку зовнішньоекономічної діяльності необхідне керівникам підприємств для обгрунтування вибору управлінських рішень, пов'язаних із набуттям підприємствами конкурентних переваг, які забезпечать їм збільшення обсягу зовнішньоекономічної діяльності, зростання прибутку, посилення ринкових позиції, зміцнення фінансового стану тощо. У представленому матеріалі доводиться необхідність урахування встановлених резервів розвитку зовнішньоекономічної діяльності підприємств під час розроблення механізмів розвитку цієї діяльності, удосконаленні технології їх застосування, виробленні управлінських рішень.

Наукова новизна виконаного дослідження полягає у розкритті сутності механізмів розвитку зовнішньоекономічної діяльності промислових підприємств, а також у в уточненні технології формування механізму розвитку зовнішньоекономічної діяльності промислових підприємств. 


\section{2. Сутність і види механізмів розвитку \\ зовнішньоекономічної діяльності промислових підприсмств}

Проведені дослідження дозволили побудувати класифікацію механізмів розвитку зовнішньоекономічної діяльності промислових підприємств: За відношеннями між векторами розвитку (процесійно-послідовний механізм; процесійно-паралельний механізм; комбінований); за тривалістю функціонування (постійно діючі механізми; тимчасово діючі механізми); за ефективністю використання (ефективні механізми; неефективні механізми).

Процесійно-послідовний механізм розвитку (передбачає поступове набуття підприємством досвіду у реалізації зовнішньоекономічної діяльності і його використання за основу при започаткуванні нових видів зовнішньоекономічної діяльності. Послідовний механізм розвитку зовнішньоекономічної діяльності застосовується тоді, коли стратегія розвитку підприємства базується на поглибленні спеціалізації виробництва, виявленні нових секторів попиту на вже освоєних ринках). Нижче наведемо компоненти цього механізму і відношення між ними

$$
\left.\begin{array}{l}
\left\{\begin{array}{c}
3 \\
X_{a} \\
a=1
\end{array}\right\} \subset R_{1} ; V_{1} ; C_{1} ;\left\{\begin{array}{c}
3 \\
X_{b} \\
b=1
\end{array}\right\} \subset R_{2} ; V_{2} ; C_{2} ; \\
\because\left[\left\{\begin{array}{c}
3 \\
X_{a} \\
a=1
\end{array}\right\} \Rightarrow\left\{\begin{array}{c}
3 \\
X_{b} \\
b=1
\end{array}\right\}\right] \Rightarrow \ldots \Rightarrow \therefore\left[\left\{\begin{array}{c}
3 \\
X_{n} \\
n=1
\end{array}\right\} \subset R_{n} ; V_{n} ; C_{n}\right],
\end{array}\right\}
$$

де $C_{1}$ - цілі розвитку зовнішньоекономічної діяльності за вектором $\left(V_{1}\right)$. В даному випадку під вектором розвитку розуміємо конкретний вид зовнішньоекономічної діяльності підприємства;

$R_{1}$ - рішення щодо реалізації цілей розвитку зовнішньоекономічної діяльності за вектором $V_{1}$;

$\left\{\begin{array}{c}3 \\ X_{a} \\ a=1\end{array}\right\},\left\{\begin{array}{c}3 \\ X_{b} \\ b=1\end{array}\right\},\left\{\begin{array}{c}3 \\ X_{n} \\ n=1\end{array}\right\}$ - множини елементів $R_{1}, V_{1}, C_{1}, R_{2}, V_{2}, C_{2}$ і $R_{n}, V_{n}, C_{n}$, відповідно, які мають часові і просторові обмеження, що випливають із стратегії і тактики розвитку зовнішньоекономічної діяльності підприємства, а саме терміни і способи реалізації, виробничі і управлінські ресурси тощо;

Множини $\left\{\begin{array}{c}3 \\ X_{a} \\ a=1\end{array}\right\},\left\{\begin{array}{c}3 \\ X_{b} \\ b=1\end{array}\right\},\left\{\begin{array}{c}3 \\ X_{n} \\ n=1\end{array}\right\}$ утворюють певне об'єднання множин $\cup\left\{\begin{array}{c}k \\ X_{y} \\ y=1\end{array}\right\}$, параметри якого повністю залежать від характеристик його компонентів, що формуються поетапно внаслідок реалізації рішень 
$R_{1}, R_{2}, R_{n}$, пов'язаних із досягнення встановлених цілей $C_{1}, C_{2}, C_{n}$ у розрізі кожного з векторів розвитку зовнішньоекономічної діяльності. У формалізованому вигляді цю особливість послідовного механізму розвитку зовнішньоекономічної діяльності промислового підприємств можна записати так:

$$
\begin{aligned}
& \exists \cup\left\{\begin{array}{c}
k \\
X_{y} \\
y=1
\end{array}\right\} \equiv\left\{\begin{array}{c}
3 \\
X_{a} \\
a=1
\end{array}\right\} \cup\left\{\begin{array}{c}
3 \\
X_{b} \\
b=1
\end{array}\right\} \cup \ldots \cup\left\{\begin{array}{c}
3_{n} \\
n=1
\end{array}\right\} ; \\
& \cup\left\{\begin{array}{c}
k \\
X_{y} \\
y=1
\end{array}\right\} \backslash\left\{\begin{array}{c}
3 \\
X_{n} \\
n=1
\end{array}\right\} \equiv \cup\left\{\begin{array}{c}
k \\
X_{y} \\
y=1
\end{array}\right\} \backslash\left[\left\{\begin{array}{c}
3 \\
X_{a} \\
a=1
\end{array}\right\} \cup\left\{\begin{array}{c}
3 \\
X_{b} \\
b=1
\end{array}\right\} \cup \ldots \cup\right] ; \\
& \cup\left\{\begin{array}{c}
k \\
X_{y} \\
y=1
\end{array}\right\} \backslash\left\{\begin{array}{c}
3 \\
X_{a} \\
a=1
\end{array}\right\} \equiv \cup\left\{\begin{array}{c}
k \\
X_{y} \\
y=1
\end{array}\right\} \backslash\left[\left\{\begin{array}{c}
3 \\
X_{b} \\
b=1
\end{array}\right\} \cup \ldots \cup\left\{\begin{array}{c}
3 \\
X_{n} \\
n=1
\end{array}\right\}\right] ; \\
& \cup\left\{\begin{array}{c}
k \\
X_{y} \\
y=1
\end{array}\right\} \backslash\left\{\begin{array}{c}
3 \\
X_{b} \\
b=1
\end{array}\right\} \equiv \cup\left\{\begin{array}{c}
k \\
X_{y} \\
y=1
\end{array}\right\} \backslash\left[\left\{\begin{array}{c}
3 \\
X_{a} \\
a=1
\end{array}\right\} \cup \ldots \cup\left\{\begin{array}{c}
3 \\
X_{n} \\
n=1
\end{array}\right\}\right] .
\end{aligned}
$$

Із наведених відношень між множинами (1) і (2) видно, що у послідовному механізмі розвитку зовнішньоекономічної діяльності має місце перетин множин. Перетин відбувається в елементах, які є спільними для $\left\{\begin{array}{c}3 \\ X_{a} \\ a=1\end{array}\right\},\left\{\begin{array}{c}3 \\ X_{b} \\ b=1\end{array}\right\},\left\{\begin{array}{c}3 \\ X_{n} \\ n=1\end{array}\right\}$. Виходячи 3 того, що $\left\{\begin{array}{c}3 \\ X_{a} \\ a=1\end{array}\right\} \Rightarrow\left\{\begin{array}{c}3 \\ X_{b} \\ b=1\end{array}\right\} \Rightarrow \ldots \Rightarrow\left\{\begin{array}{c}3 \\ X_{n} \\ n=1\end{array}\right\}$, то спільним елементом є набутий досвід реалізації експортно-імпортних операцій, створенні правила і процедури, організаційна структура управління зовнішньоекономічною діяльністю, джерела інформації і способи ії отримання тощо. Позначивши спільний елемент множин $\left\{\begin{array}{c}3 \\ X_{a} \\ a=1\end{array}\right\},\left\{\begin{array}{c}3 \\ X_{b} \\ b=1\end{array}\right\},\left\{\begin{array}{c}3 \\ X_{n} \\ n=1\end{array}\right\}$ як $d$ продемонструємо явище перетину за допомогою аксіоматики множин Цермело-Френкеля (ZFC)

$$
\begin{aligned}
& \left\{\begin{array}{c}
3 \\
X_{a} \\
a=1
\end{array}\right\} \cap\left\{\begin{array}{c}
3 \\
X_{b} \\
b=1
\end{array}\right\}=\left[d \mid d \in\left\{\begin{array}{c}
3 \\
X_{a} \\
a=1
\end{array}\right\} \wedge d \in\left\{\begin{array}{c}
3 \\
X_{b} \\
b=1
\end{array}\right\}\right] ; \\
& \left\{\begin{array}{c}
3 \\
X_{a} \\
a=1
\end{array}\right\} \cap\left\{\begin{array}{c}
3 \\
X_{n} \\
n=1
\end{array}\right\}=\left[d \mid d \in\left\{\begin{array}{c}
3 \\
X_{a} \\
a=1
\end{array}\right\} \wedge d \in\left\{\begin{array}{c}
3 \\
X_{n} \\
n=1
\end{array}\right\}\right] ; \\
& \left\{\begin{array}{c}
3 \\
X_{b} \\
b=1
\end{array}\right\} \cap\left\{\begin{array}{c}
3 \\
X_{n} \\
n=1
\end{array}\right\}=\left[d \mid d \in\left\{\begin{array}{c}
3 \\
X_{b} \\
b=1
\end{array}\right\} \wedge d \in\left\{\begin{array}{c}
3 \\
X_{n} \\
n=1
\end{array}\right\}\right] .
\end{aligned}
$$

На рис. 1 наведено логіку відношень між компонентами процесійно-послідовного механізму розвитку зовнішньоекономічної діяльності. Процесійно-паралельний механізм розвитку, на відміну від процесійно-послідовного і процесійно-паралельного механізмів, передбачає 
започаткування кількох незалежних між собою векторів розвитку зовнішньоекономічної діяльності цілі, і засоби досягнення яких у межах окремих видів зовнішньоекономічної діяльності не перетинаються.

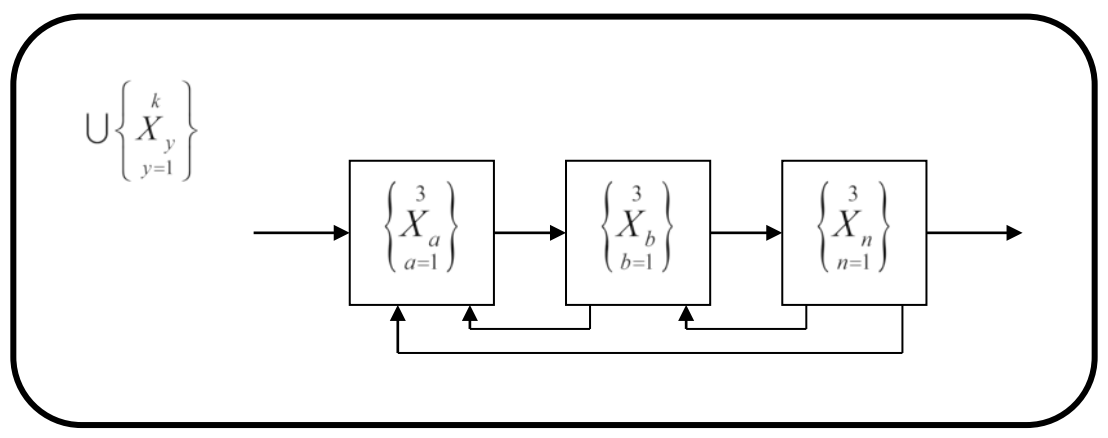

Рис. 1. Відношення між компонентами процесійно-послідовного механізму розвитку зовнішньоекономічної діяльності

Процесійно-паралельний механізм розвитку зовнішньоекономічної діяльності застосовується тоді, коли стратегія розвитку підприємства базується на диверсифікації видів діяльності, що має за мету розподілити ризики зовнішньоекономічної діяльності і джерела отримання прибутку. Основою логіки досягнення цієї мети за допомогою диверсифікації векторів розвитку зовнішньоекономічної діяльності $є$ те, що окремі види зовнішньоекономічної діяльності зазнають впливу різних за характером факторів. Як наслідок, ймовірність настання небажаних подій у межах кожного з векторів є неоднаковою). Компоненти паралельного механізму розвитку зовнішньоекономічної діяльності перебувають між собою у таких відношеннях:

$$
\begin{aligned}
& \exists\left\{\begin{array}{c}
k \\
X_{y} \\
y=1
\end{array}\right\} \forall\left\{\begin{array}{c}
3 \\
X_{a} \\
a=1
\end{array}\right\}\left[\left\{\begin{array}{c}
3 \\
X_{b} \\
b=1
\end{array}\right\} \notin\left\{\begin{array}{c}
3 \\
X_{a} \\
a=1
\end{array}\right\}\right] ; \\
& \exists\left\{\begin{array}{c}
k \\
X_{y} \\
y=1
\end{array}\right\} \forall\left\{\begin{array}{c}
3 \\
X_{b} \\
b=1
\end{array}\right\}\left[\left\{\begin{array}{c}
3 \\
X_{b} \\
b=1
\end{array}\right\} \notin\left\{\begin{array}{c}
k \\
X_{y} \\
y=1
\end{array}\right\}\right] ; \\
& \cdots \ldots \\
& \exists\left\{\begin{array}{c}
k \\
X_{y} \\
y=1
\end{array}\right\} \forall\left\{\begin{array}{c}
3 \\
X_{n} \\
n=1
\end{array}\right\}\left[\left\{\begin{array}{c}
3 \\
X_{n} \\
n=1
\end{array}\right\} \notin\left\{\begin{array}{c}
k \\
X_{y} \\
y=1
\end{array}\right\}\right] \cdot
\end{aligned}
$$




\section{Chapter «Economic sciences»}

Як бачимо, тут йдеться про наявність порожньої множини $\left\{\begin{array}{c}k \\ X_{y} \\ y=1\end{array}\right\}$, тобто множини, яка не містить ні одного елемента. Порожня множина є своєю підмножиною, але не є своїм елементом. Враховуючи це потужність порожньої множини і потужність кожного з векторів розвитку зовнішньоекономічної діяльності не дорівнюють один одному

$$
\operatorname{card}\left(\left\{\begin{array}{c}
k \\
X_{y} \\
y=1
\end{array}\right\}\right) \neq\left\{\begin{array}{c}
\operatorname{card}\left(\left\{\begin{array}{c}
3 \\
X_{a} \\
a=1
\end{array}\right\}\right) \\
\operatorname{card}\left(\left\{\begin{array}{c}
3 \\
X_{b} \\
b=1
\end{array}\right\}\right) . \\
\ldots \ldots \ldots \\
\operatorname{card}\left(\left\{\begin{array}{c}
3 \\
X_{n} \\
n=1
\end{array}\right\}\right)
\end{array}\right.
$$

На рис. 2 наведено логіку відношень між компонентами процесійно-паралельного механізму розвитку зовнішньоекономічної діяльності.

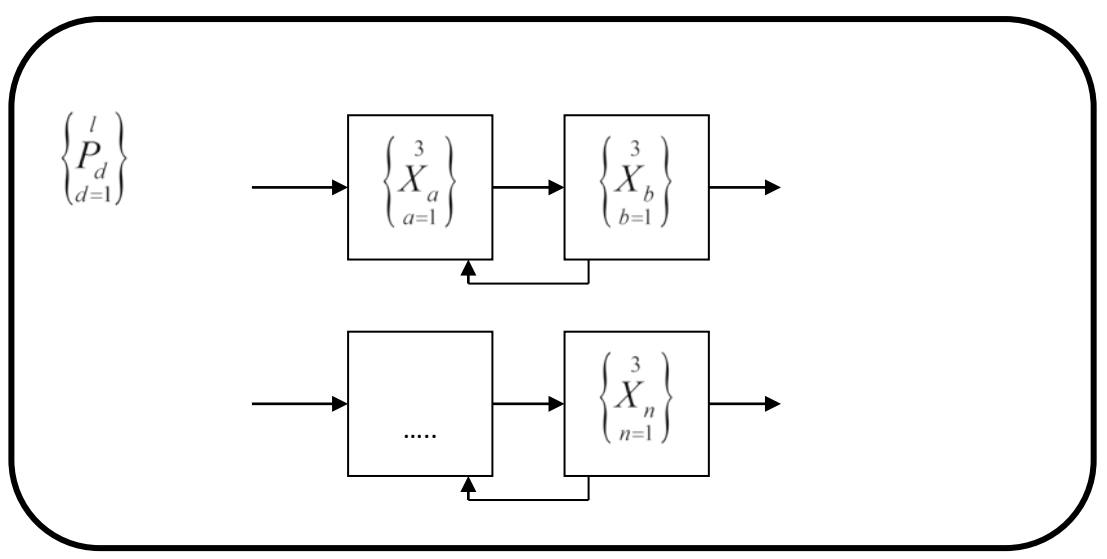

Рис. 2. Відношення між компонентами процесійно-паралельного механізму розвитку зовнішньоекономічної діяльності

Комбінований механізм розвитку зовнішньоекономічної діяльності $\epsilon$ поєднанням послідовного і паралельного механізмів. Це конгломеративна форма встановлення і реалізації цілей у сфері зовнішньоекономічної діяльності підприємства. Особливістю комбінованого механізму є те, 
що усі вектори розвитку зовнішньоекономічної діяльності розподілено на дві групи - ті, які пов'язані між собою цілями і засоби реалізації, i, ті, які $\epsilon$ незалежними. Емпіричні дослідження дозволяють стверджувати, що конгломеративна форма розвитку зовнішньоекономічної діяльності виникає на певній стадії розвитку системи менеджменту суб'єкта зовнішньоекономічної діяльності. Характерною особливістю цієї стадії є наявність як мінімум трьох векторів розвитку зовнішньоекономічної діяльності, два 3 яких формуються на засадах застосування послідовного механізму розвитку. Відношення між компонентами конгломерату запишемо так:

$$
\left.\begin{array}{l}
\left.\left\{\begin{array}{c}
3 \\
X_{a} \\
a=1
\end{array}\right\} \Rightarrow\left\{\begin{array}{c}
3 \\
X_{b} \\
b=1
\end{array}\right\} \Rightarrow \ldots \Rightarrow\left\{\begin{array}{c}
3^{3} \\
n=1
\end{array}\right\} \equiv\left\{\begin{array}{c}
k \\
X_{y} \\
y=1
\end{array}\right\}\right\} \Rightarrow \cup\left\{\begin{array}{c}
n \\
Z_{j} \\
j=1
\end{array}\right\}, \\
\left\{\begin{array}{c}
m \\
Y_{i} \\
i=1
\end{array}\right\} \\
\operatorname{card}\left(\cup\left\{\begin{array}{c}
k \\
X_{y} \\
y=1
\end{array}\right\}\right) \wedge \operatorname{card}\left(\left\{\begin{array}{c}
m \\
Y_{i} \\
i=1
\end{array}\right\}\right) \equiv \operatorname{card}\left(\cup\left\{\begin{array}{c}
n \\
Z_{j} \\
j=1
\end{array}\right\}\right)
\end{array}\right\}
$$

де $\left\{\begin{array}{c}m \\ Y_{i} \\ i=1\end{array}\right\}$ - множина елементів, які забезпечують розвиток зовнішньоекономічної діяльності промислового підприємства за вектором, параметри розвитку якого не залежать від інших векторів;

$\cup\left\{\begin{array}{l}n \\ Z_{j} \\ j=1\end{array}\right\}$ - об'єднання множин елементів, які забезпечують розвиток зовнішньоекономічної діяльності промислового підприємства як за пов'язаними між собою векторами, так і за векторами, що є незалежними один від одного.

На рис. 3 показано логіку відношень між компонентами механізму розвитку зовнішньоекономічної діяльності, що побудований на засадах конгломератного підходу.

За умови високого рівня розвитку систем менеджменту промислових підприємств значною $є$ ймовірність перетворення конгломератних механізмів розвитку зовнішньоекономічної діяльності промислових підприємств у системні. Ці механізми відрізняються від конгломератних тим, що у них усі вектори розвитку зовнішньоекономічної діяльності взаємозалежні і взаємопов'язані один з одним. Проведені дослідження показали, що перевагою їх застосування стосовно конгломератних механізмів є те, що вони уможливлюють отримання підприємствами позитивних синергічних ефектів у формі економії на 


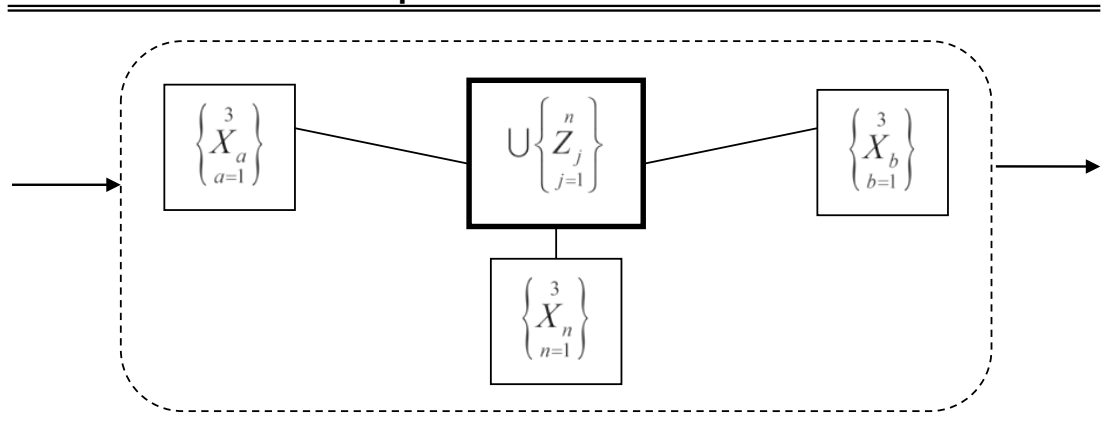

Рис. 3. Відношення між компонентами механізму розвитку зовнішньоекономічної діяльності, що побудований на засадах конгломератного підходу

масштабі у розрізі транспортних, адміністративних, маркетингових та інших логістичних витрат ${ }^{1}$. На рис. 4 показано логіку відношень між компонентами механізму розвитку зовнішньоекономічної діяльності, що побудований на засадах системного підходу.

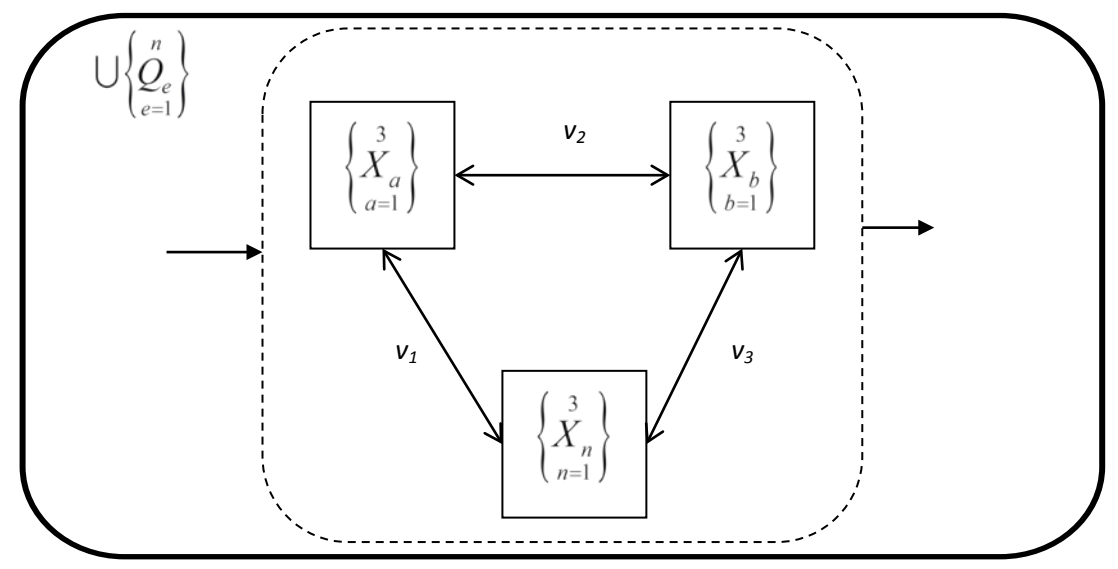

Рис. 4. Відношення між компонентами механізму розвитку зовнішньоекономічної діяльності, що побудований на засадах системного підходу

\footnotetext{
1 Логістичні витрати промислового підприємства є від'ємними потоками фінансових або інших ресурсів, які виникають під час постачання підприємства ресурсами, виробництва і збуту готової продукції, зумовлюють формування і використання активів підприємства та характер фінансових результатів його діяльності [1].
} 
Взаємозалежні елементи v1, v2 i v3 утворюють множину $\left\{\begin{array}{c}3 \\ V_{c} \\ c=1\end{array}\right\}$

$$
\left\{\begin{array}{c}
3 \\
V_{c} \\
c=1
\end{array}\right\} \Rightarrow e \Rightarrow\left\{\begin{array}{l}
\left\{\begin{array}{c}
k \\
X_{y} \\
y=1
\end{array}\right\} \backslash\left\{\begin{array}{c}
k \\
X_{y} \\
y=1
\end{array}\right\}_{b}, \\
\left\{\begin{array}{c}
m \\
Y_{i} \\
i=1
\end{array}\right\}_{z} \backslash\left\{\begin{array}{c}
m \\
Y_{i} \\
i=1
\end{array}\right\}_{b}
\end{array}\right.
$$

де $e$ - синергічні ефекти; $z$ - звітний період; $b$ - базовий період.

Враховуючи це, потужність механізму, який сформований на основі системного підходу відрізняється від потужності механізму, який побудований як конгломерат. Продемонструємо це за допомогою такого виразу:

$$
\begin{aligned}
& \operatorname{card}\left(\bigcup\left\{\begin{array}{c}
n \\
Z_{j} \\
j=1
\end{array}\right\}\right) \neq \operatorname{card}\left(\bigcup\left\{\begin{array}{c}
n \\
Q_{e} \\
e=1
\end{array}\right\}\right) \because \operatorname{card}\left(\cup\left\{\begin{array}{c}
n \\
Z_{j} \\
j=1
\end{array}\right\}\right) \backslash \operatorname{card}\left(\bigcup\left\{\begin{array}{c}
n \\
Q_{e} \\
e=1
\end{array}\right\}\right)=\left\{\begin{array}{l}
\left\{\begin{array}{c}
k \\
X_{y} \\
y=1
\end{array}\right\}_{z} \backslash\left\{\begin{array}{c}
k \\
X_{y} \\
y=1
\end{array}\right\}_{b} \\
\left\{\begin{array}{c}
m \\
Y_{i} \\
i=1
\end{array}\right\}_{z} \backslash \backslash\left\{\begin{array}{c}
m \\
Y_{i} \\
i=1
\end{array}\right\}_{b}
\end{array}\right. \\
& \because \cup\left\{\begin{array}{l}
n \\
Q_{e} \\
e=1
\end{array}\right\} \subset \cup\left\{\begin{array}{c}
n \\
Z_{j} \\
j=1
\end{array}\right\} \wedge\left\{\begin{array}{c}
\left\{\begin{array}{c}
k \\
X_{y} \\
y=1
\end{array}\right\}_{z} \backslash\left\{\begin{array}{c}
k \\
X_{y} \\
y=1
\end{array}\right\}_{b} \\
\left\{\begin{array}{l}
m \\
Y_{i} \\
i=1
\end{array}\right\}_{z} \backslash\left\{\begin{array}{l}
m \\
Y_{i} \\
i=1
\end{array}\right\}_{b}
\end{array}\right.
\end{aligned}
$$

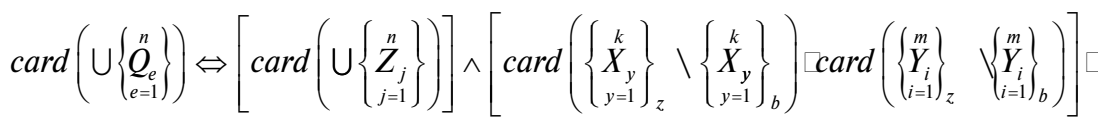

де $\cup\left\{\begin{array}{l}n \\ Q_{e} \\ e=1\end{array}\right\}-$ об'єднання множин у механізмі розвитку зовнішньоекономічної діяльності, що побудований на засадах системного підходу.

Кожен з вищенаведених механізмів може функціонувати постійно або тимчасово у залежності від характеру цілей розвитку зовнішньоекономічної діяльності, наявності стратегічного плану їх досягнення. Проведені дослідження показали, що в умовах швидкої зміни ринкової кон'юнктури на багатьох промислових підприємствах приймаються рішення щодо реалізації тих чи інших експортно-імпортні операцій не за результатами попередньо сформованих стратегічних планів, а в наслідок одержання і оброблення оперативної управлінської інформації. Здебільшого такі факти мають місце стосовно видів діяльності, які не є традиційними для промислових підприємств, зокрема йдеться про 


\section{Chapter «Economic sciences»}

реалізацію фінансово-інвестиційних операцій, а також надання послуг консалтингового або інжинірингового характеру. Попри це слід відзначити, що в підприємницьких колах сьогодні викликають підвищений інтерес способи забезпечення інформативності, науково-обгрунтованості прогнозів, які лягають в основу стратегічного планування розвитку зовнішньоекономічної діяльності. Тобто має місце тенденція до застосування комбінованих механізмів розвитку зовнішньоекономічної діяльності, які формуються і застосовуються як на основі стратегічних, так і оперативних рішень. Критеріями ефективності використання механізмів розвитку зовнішньоекономічної діяльності $\epsilon$ досягнення в очікувані терміни встановлених оперативних, тактичних і стратегічних цілей, сукупність реалізації яких забезпечує конкурентоспроможність підприємства.

\section{3. Технологія формування механізму розвитку}

\section{зовнішньоекономічної діяльності промислових підприємств}

Розвиток зовнішньоекономічної діяльності супроводжується вибором нових векторів реалізації експортно-імпортних операцій, встановленням відповідних їм цілей, прийняттям нових управлінських рішень i їх реалізацією на основі наявного потенціалу розвитку зовнішньоекономічної діяльності та інформації про стан зовнішнього середовища, зокрема про запити споживачів, цінову конкуренцію, появу нових тенденцій тощо. На цьому етапі формування механізму розвитку зовнішньоекономічної діяльності підприємства найбільш адекватно відображає аксіома приєднання, яка звучить так - якщо $x$ і $y$ - множини, то існує така множина $w$, приєднання $x$ і $y$, чиї елементи - тільки у і елементи $x$. Застосуємо використані у параграфі 3.1 позначення для формалізованого опису даного етапу технології формування механізму розвитку зовнішньоекономічної діяльності промислового підприємства на основі використання аксіоми приєднання

$$
\forall\left\{\begin{array}{c}
3 \\
X_{a} \\
a=1
\end{array}\right\} \forall\left\{\begin{array}{c}
3 \\
X_{b} \\
b=1
\end{array}\right\} \exists\left\{\begin{array}{c}
\Theta \\
X_{z} \\
z=1
\end{array}\right\} \forall d\left[d \in\left\{\begin{array}{c}
\Theta \\
X_{z} \\
z=1
\end{array}\right\} \leftrightarrow\left(d \in\left\{\begin{array}{c}
3 \\
X_{a} \\
a=1
\end{array}\right\} \vee d=\left\{\begin{array}{c}
3 \\
X_{b} \\
b=1
\end{array}\right\}\right)\right],
$$

де $\left\{\begin{array}{c}\Theta \\ X_{z} \\ z=1\end{array}\right\}$ - множина елементів механізму розвитку зовнішньоекономічної діяльності промислового підприємства, яка містить елементи множин тільки $\left\{\begin{array}{c}3 \\ X_{a} \\ a=1\end{array}\right\} \wedge\left\{\begin{array}{c}3 \\ X_{b} \\ b=1\end{array}\right\}$. 
Вищенаведений вираз демонструє операцію приєднання нової множини $\left\{\begin{array}{c}3 \\ X_{b} \\ b=1\end{array}\right\}$ до існуючої множини $\left\{\begin{array}{c}3 \\ X_{a} \\ a=1\end{array}\right\}$, наслідком чого є виникнення множини $\left\{\begin{array}{c}\stackrel{\ominus}{X} \\ z=1\end{array}\right\}$. В даному випадку $d$ є таким елементом множин $\left\{\begin{array}{c}\stackrel{\ominus}{X} \\ X_{z}\end{array}\right\}$, який є спільним, як для множини $\left\{\begin{array}{c}3 \\ X_{a} \\ a=1\end{array}\right\}$, так і для множини $\left\{\begin{array}{c}3 \\ X_{b} \\ b=1\end{array}\right\}$.

У відповідності до системи аксіом ZFC аксіома приєднання тісно пов'язана із аксіомою екстенсіональності (якщо дві множини мають одні і ті ж елементи, то вони тотожні)

$$
\forall\left\{\begin{array}{c}
X_{a} \\
a=1
\end{array}\right\} \forall\left\{\begin{array}{c}
3 \\
X_{b} \\
b=1
\end{array}\right\}\left[\forall\left\{\begin{array}{c}
\Theta \\
X_{z} \\
z=1
\end{array}\right\}\left[\left\{\begin{array}{c}
\Theta \\
X_{z} \\
z=1
\end{array}\right\} \in\left\{\begin{array}{c}
3 \\
X_{a} \\
a=1
\end{array}\right\} \leftrightarrow\left\{\begin{array}{c}
\Theta \\
X_{z} \\
z=1
\end{array}\right\} \in\left\{\begin{array}{c}
3 \\
X_{b} \\
b=1
\end{array}\right\}\right] \rightarrow\left\{\begin{array}{c}
3 \\
X_{a} \\
a=1
\end{array}\right\}=\left\{\begin{array}{c}
3 \\
X_{b} \\
b=1
\end{array}\right\}\right] .
$$

Тут йдеться про те, що коли підприємство формує механізм розвитку зовнішньоекономічної діяльності у розрізі різних векторів за однаковим шаблоном (алгоритмом), то кожен новий приєднаний вектор розвитку за змістовим наповненням не відрізняється від існуючого, зокрема у розрізі способу формування системи цілей, прийняття і реалізації рішень щодо їхнього виконання, урахування факторів, внутрішнього і зовнішнього середовищ тощо.

Проведені дослідження дозволяють стверджувати, що процес формування механізму розвитку зовнішньоекономічної діяльності промислового підприємства окрім явищ приєднання нових векторів розвитку до вже існуючих, супроводжується також явищем узгодження встановлюваних цілей і методів їхнього досягнення із оріснтирами стратегічного розвитку підприємства і тактикою виконання встановлених завдань. 3 позиції системи ZFC цей факт можна описати за допомогою аксіоми схеми виділення

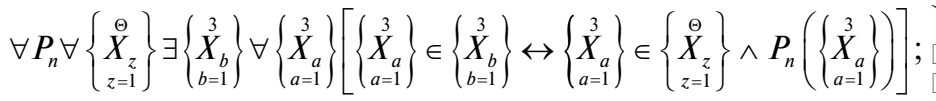

$$
\begin{aligned}
& \forall I_{n} \forall\left\{\begin{array}{c}
\stackrel{\ominus}{X_{z}} \\
z=1
\end{array}\right\} \exists\left\{\begin{array}{c}
3 \\
X_{b} \\
b=1
\end{array}\right\} \forall\left\{\begin{array}{c}
3 \\
X_{a} \\
a=1
\end{array}\right\}\left[\left\{\begin{array}{c}
3 \\
X_{a} \\
a=1
\end{array}\right\} \in\left\{\begin{array}{c}
3 \\
X_{b} \\
b=1
\end{array}\right\} \leftrightarrow\left\{\begin{array}{c}
3 \\
X_{a} \\
a=1
\end{array}\right\} \in\left\{\begin{array}{c}
\Theta \\
X_{z} \\
z=1
\end{array}\right\} \wedge I_{n}\left(\left\{\begin{array}{c}
3 \\
X_{a} \\
a=1
\end{array}\right)\right)\right] \\
& \forall C_{n} \forall\left\{\begin{array}{c}
\stackrel{\ominus}{X}_{z} \\
z=1
\end{array}\right\} \exists\left\{\begin{array}{c}
3 \\
X_{b} \\
b=1
\end{array}\right\} \forall\left\{\begin{array}{c}
3 \\
X_{a} \\
a=1
\end{array}\right\}\left[\left\{\begin{array}{c}
3 \\
X_{a} \\
a=1
\end{array}\right\} \in\left\{\begin{array}{c}
3 \\
X_{b} \\
b=1
\end{array}\right\} \leftrightarrow\left\{\begin{array}{c}
3 \\
X_{a} \\
a=1
\end{array}\right\} \in\left\{\begin{array}{c}
\Theta \\
X_{z} \\
z=1
\end{array}\right\} \wedge C_{n}\left(\left\{\begin{array}{c}
3 \\
X_{a} \\
a=1
\end{array}\right\}\right)\right] \\
& \forall \square_{n} \forall\left\{\begin{array}{c}
\stackrel{\ominus}{X} \\
X_{z} \\
z=1
\end{array}\right\} \exists\left\{\begin{array}{c}
3 \\
X_{b} \\
b=1
\end{array}\right\} \forall\left\{\begin{array}{c}
3 \\
X_{a} \\
a=1
\end{array}\right\}\left[\left\{\begin{array}{c}
3 \\
X_{a} \\
a=1
\end{array}\right\} \in\left\{\begin{array}{c}
3 \\
X_{b} \\
b=1
\end{array}\right\} \leftrightarrow\left\{\begin{array}{c}
3 \\
X_{a} \\
a=1
\end{array}\right\} \in\left\{\begin{array}{c}
\stackrel{\ominus}{X_{z}} \\
z=1
\end{array}\right\} \wedge \square_{n}\left(\left\{\begin{array}{c}
3 \\
X_{a} \\
a=1
\end{array}\right)\right)\right] \square
\end{aligned}
$$

У технології формування механізму розвитку зовнішньоекономічної діяльності підприємства аксіома виділення стосується усіх еле- 


\section{Chapter «Economic sciences»}

ментів механізму, про які згадувалось у попередньому розділі, окрім елемента $V_{n}$, оскільки саме вектори розвитку характеризуються спільними або відмінними властивостями, що визначають змістові, процедурні, кількісні та якісні властивості кожного із започаткованих видів зовнішньоекономічної діяльності підприємства.

Дослідження показали, що під впливом факторів зовнішнього середовища промислового підприємств управлінська інформація про зміни споживчих запитів, цінові коливання тощо є підставою для започаткування таких видів зовнішньоекономічної діяльності, які не перетинаються із загальною системою цілей розвитку підприємства. Як наслідок, управлінські рішення щодо реалізації цих цілей значною мірою є автономними, незалежними від рішень, прийнятих для реалізації цілей у розрізі існуючих векторів розвитку зовнішньоекономічної діяльності підприємства. Передусім цей висновок актуальний в умовах розвитку експортно-імпортних операцій за векторами, що передбачають досягнення встановлених цілей на основі аутсорсингу, який супроводжується використанням виробничого, логістичного, інноваційного та інших видів потенціалу бізнес-партнерів [2]. Враховуючи вищесказане в умовах аутсорсингу промислові підприємства можуть розвивати експортно-імпортну діяльність за векторами, які незалежні від вже освоєних підприємством видів зовнішньоекономічної діяльності. 3 позиції аксіоми регулярності цей висновок можна описати таким виразом

$$
\forall\left\{\begin{array}{c}
k \\
X_{y} \\
y=1
\end{array}\right\}\left\{\exists\left\{\begin{array}{c}
3 \\
X_{j} \\
j=1
\end{array}\right\}\left(\left\{\begin{array}{c}
3 \\
X_{j} \\
j=1
\end{array}\right\} \in\left\{\begin{array}{c}
k \\
X_{y} \\
y=1
\end{array}\right\}\right) \rightarrow \exists\left\{\begin{array}{c}
3 \\
X_{j} \\
j=1
\end{array}\right\}\left(\left\{\begin{array}{c}
3 \\
X_{j} \\
j=1
\end{array}\right\} \in\left\{\begin{array}{c}
k \\
X_{y} \\
y=1
\end{array}\right\} \wedge \neg \exists g\left(g \in\left\{\begin{array}{c}
k \\
X_{y} \\
y=1
\end{array}\right\} \wedge g \in\left\{\begin{array}{c}
3 \\
X_{j} \\
j=1
\end{array}\right\}\right)\right)\right)
$$

де g є таким елементом $\left\{\begin{array}{c}3 \\ X_{j} \\ j=1\end{array}\right\} \mathrm{i}\left\{\begin{array}{c}k \\ X_{y} \\ y=1\end{array}\right\}$, перетин яких є порожньою множиною. Тобто g є незалежним за цілями і засобами досягнення вектором розвитку зовнішньоекономічної діяльності підприємства.

У цілому на завершальному етапі технології формування механізму розвитку зовнішньоекономічної діяльності промислового підприємства застосовується схема перетворення (аксіома підстановки), яку можна записати так

$\forall V_{1}, \exists C_{1}: P\left(V_{1}, C_{1}\right) \rightarrow \forall\left\{\begin{array}{c}3 \\ X_{a} \\ a=1\end{array}\right\}, \exists\left\{\begin{array}{c}3 \\ X_{b} \\ b=1\end{array}\right\}, \forall C_{1}: C_{1} \in\left\{\begin{array}{c}3 \\ X_{b} \\ b=1\end{array}\right\} \Leftrightarrow \exists V_{1} \in\left\{\begin{array}{c}3 \\ X_{a} \\ a=1\end{array}\right\}: P\left(V_{1}, C_{1}\right)$,

Досягнення стратегічних орієнтирів підприємства відбувається у розрізі реалізації цілей за різними векторами, в тому числі векторами 
розвитку зовнішньоекономічної діяльності підприємства. 3 огляду на це, забезпечення конкурентоспроможності підприємства, його фінансової стійкості і прибутковості вимагає застосування декомпозиції управління, що базується на постійному посиленні ролі сучасних інформаційних технологій для акумулювання, оперативного аналітичного оброблення і використання даних внутрішнього і зовнішнього середовищ для оптимізації шляхів досягнення встановлених цілей.

Об'єднання різних векторів розвитку зовнішньоекономічної діяльності в один призводить до виникнення булеана

$$
\begin{aligned}
& \forall\left\{\begin{array}{c}
\gamma \\
X_{\lambda} \\
\lambda=1
\end{array}\right\} \exists \cup\left\{\begin{array}{c}
k \\
X_{y} \\
y=1
\end{array}\right\} \forall\left\{\begin{array}{c}
\beta \\
X_{\theta} \\
\theta=1
\end{array}\right\}\left(\left\{\begin{array}{c}
\beta \\
X_{\theta} \\
\theta=1
\end{array}\right\} \in \cup\left\{\begin{array}{c}
k \\
X_{y} \\
y=1
\end{array}\right\} \leftrightarrow\left\{\begin{array}{c}
\beta \\
X_{\theta} \\
\theta=1
\end{array}\right\} \subseteq\left\{\begin{array}{c}
\gamma \\
X_{\lambda} \\
\lambda=1
\end{array}\right\}\right) ; \\
& \left\{\begin{array}{c}
\beta \\
X_{\theta} \\
\theta=1
\end{array}\right\} \subseteq\left\{\begin{array}{c}
\gamma \\
X_{\lambda} \\
\lambda=1
\end{array}\right\} \leftrightarrow \forall\left\{\begin{array}{c}
\Psi \\
X_{\Omega}
\end{array}\right\}\left\{\left\{\begin{array}{c}
\Psi \\
X_{\Omega} \\
\Omega=1
\end{array}\right\} \in\left\{\begin{array}{c}
\beta \\
X_{\theta} \\
\theta=1
\end{array}\right\} \rightarrow\left\{\begin{array}{l}
\Psi \\
X_{\Omega} \\
\Omega=1
\end{array}\right\} \in\left\{\begin{array}{c}
\gamma \\
X_{\lambda} \\
\lambda=1
\end{array}\right\}\right) ; \\
& \cup\left\{\begin{array}{c}
k \\
X_{y} \\
y=1
\end{array}\right\} \square\left(\left\{\begin{array}{c}
\gamma \\
X_{\lambda} \\
\lambda=1
\end{array}\right\} \square\left(\left\{\begin{array}{c}
\beta \\
X_{\theta} \\
\theta=1
\end{array}\right\} \square\left\{\begin{array}{c}
\Psi \\
X_{\Omega} \\
\Omega=1
\end{array}\right\}\right)\right) ;\left(\left\{\begin{array}{c}
\beta \\
X_{\theta} \\
\theta=1
\end{array}\right\} \in\left\{\begin{array}{c}
\gamma \\
X_{\lambda} \\
\lambda=1
\end{array}\right\}\right) \leftrightarrow\left(\square \in\left\{\begin{array}{c}
\beta \\
X_{\theta} \\
\theta=1
\end{array}\right\} \square \square \in\left\{\begin{array}{c}
\gamma \\
X_{\lambda} \\
\lambda=1
\end{array}\right\}\right) ; \\
& \left(\left\{\begin{array}{c}
\Psi \\
X_{\Omega} \\
\Omega=1
\end{array}\right\} \in\left\{\begin{array}{c}
\beta \\
X_{\theta} \\
\theta=1
\end{array}\right\}\right) \leftrightarrow\left(\square \in\left\{\begin{array}{c}
\Psi \\
X_{\Omega} \\
\Omega=1
\end{array}\right\} \square \square \in\left\{\begin{array}{c}
\beta \\
X_{\theta} \\
\theta=1
\end{array}\right\}\right) \square
\end{aligned}
$$

де $\cup\left\{\begin{array}{c}k \\ X_{y} \\ y=1\end{array}\right\}$ - булеан, що складається з підмножин $\left\{\begin{array}{c}\gamma \\ X_{\lambda} \\ \lambda=1\end{array}\right\},\left\{\begin{array}{c}\beta \\ X_{\theta} \\ \theta=1\end{array}\right\} \mathrm{i}\left\{\begin{array}{c}\Psi \\ X_{\Omega} \\ \Omega=1\end{array}\right\}$, які репрезентують виникнення спеціалізації і диверсифікації у межах певного вектора розвитку зовнішньоекономічної діяльності підприємства;

$$
\begin{aligned}
& \varphi \text { - спільний елемент для множин }\left\{\begin{array}{c}
\gamma \\
X_{\lambda} \\
\lambda=1
\end{array}\right\} \text { i }\left\{\begin{array}{c}
\beta \\
X_{\theta} \\
\theta=1
\end{array}\right\} ; \\
& \propto-\text { спільний елемент для множин }\left\{\begin{array}{c}
\Psi \\
X_{\Omega} \\
\Omega=1
\end{array}\right\} \text { i }\left\{\begin{array}{c}
\beta \\
X_{\theta} \\
\theta=1
\end{array}\right\} .
\end{aligned}
$$

Таким чином, за результатами проведених досліджень ідентифіковано етапи технологічного процесу формування механізму розвитку зовнішньоекономічної діяльності підприємства (рис. 5) [3].

Формування механізму відбувається на основі аналітичної обробки даних внутрішнього і зовнішнього середовищ підприємства щодо перспектив розвитку зовнішньоекономічної діяльності. Зовнішнє середовище зазвичай досліджується на предмет [4; 6]:

- виявлення незадоволеного попиту споживачів;

- ідентифікування характеру змін у споживчих уподобаннях; 

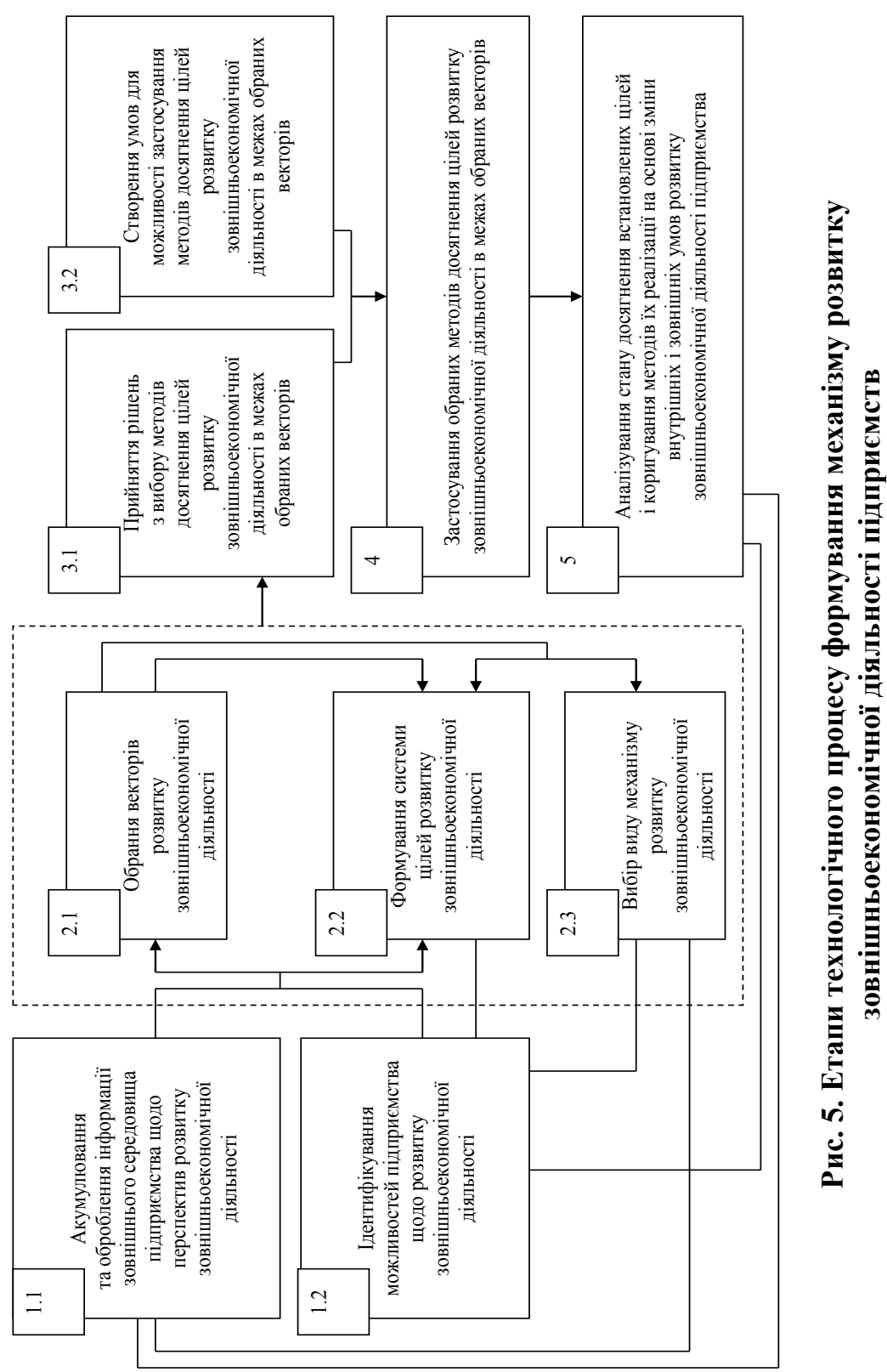
- встановлення явищ і тенденцій, які важливі з точки зору їхнього впливу на конкурентоспроможність підприємства, стійкість його ринкових позицій.

Внутрішнє середовище підприємства є джерелом інформації про його можливості (потенціал) розвитку зовнішньоекономічної діяльності. На основі співставлення даних про ринкові можливості і здатність підприємства їх використати відбувається обрання векторів розвитку зовнішньоекономічної діяльності підприємства, формування системи цілей у межах кожного з векторів і вибір виду механізму розвитку зовнішньоекономічної діяльності, що є підставою для прийняття рішень 3 вибору методів досягнення цілей розвитку зовнішньоекономічної діяльності. Дослідження показали, що незалежно від змістового наповнення обрані рішення супроводжуються кількома альтернативами [5]:

- започаткування нового виду зовнішньоекономічної діяльності як незалежного вектору розвитку, цілі і засоби досягнення яких непов'язані з іншими векторами; розвиток зовнішньоекономічної діяльності за вектором, який споріднений з іншими векторами, що вимагає ретельного аналізу узгодженості встановлених цілей і способів їх реалізації;

- створення конгломерату або системи векторів розвитку зовнішньоекономічної діяльності, яка включає низку локальних формувань, які можуть як мати, так і не мати часових обмежень реалізації цілей; ліквідація тих векторів розвитку експортної імпортної діяльності, цілі яких досягнуто або їх реалізація стала неактуальною внаслідок зміни умов розвитку зовнішньоекономічної діяльності промислового підприємства.

Емпіричні та експертні дані вказують на те, що перехід від процесу прийняття рішень до процесу їх реалізації вимагає створення умов для можливості застосування методів досягнення цілей розвитку зовнішньоекономічної діяльності в межах обраних векторів. Йдеться про організаційне, інформаційне, матеріально-технічне, фінансове, кадрове забезпечення реалізації рішень. Ці умови створюються шляхом:

- доведення рішень до їх виконавців;

- наданням необхідних повноважень виконавцям рішень із коригуванням субординації відносин між окремими посадовими особами i підрозділами підприємства;

- уможливлення доступу до баз даних і програмних продуктів, які необхідні для аналітичної обробки управлінської інформації та реалізації конкретних операцій; 


\section{Chapter «Economic sciences»}

- забезпечення виконавців рішень матеріальними, фінансовими та іншими ресурсами, без використання яких неможливо виконати ухвалене рішення тощо.

Заключними етапами технологічного процесу формування механізму розвитку зовнішньоекономічної діяльності промислових підприємств $\epsilon$ застосування методів досягнення цілей розвитку зовнішньоекономічної діяльності в межах обраних векторів, аналізування стану досягнення встановлених цілей і коригування методів їх реалізації на основі зміни внутрішніх і зовнішніх умов розвитку зовнішньоекономічної діяльності підприємства (рис. 6).

Розвиток зовнішньоекономічної діяльності керівниками промислових підприємств у відповідності до виділених етапів технологічного процесу сприятиме оптимізації управлінських рішень, спрямованих на розвиток зовнішньоекономічної діяльності.

\section{4. Висновки}

Доведено, що механізми розвитку зовнішньоекономічної діяльності виникають не спонтанно, а формуються на основі урахування тих обставин, які $\epsilon$ визначальними при виборі векторів і цілей розвитку зовнішньоекономічної діяльності, а також виборі управлінських рішень щодо реалізації встановлених цілей. Ці умови вимагають застосування певної технології формування механізму розвитку зовнішньоекономічної діяльності із урахуванням цілей розвитку зовнішньоекономічної діяльності, рівня розвитку системи менеджменту підприємства i наявного досвіду реалізації зовнішньоекономічної операцій за різними векторами. На основі застосування системи аксіом ZFC обгрунтовано, що такими етапами є: акумулювання та оброблення інформації зовнішнього зовнішньоекономічної діяльності; ідентифікування можливостей підприємства щодо розвитку зовнішньоекономічної діяльності; обрання векторів розвитку зовнішньоекономічної; формування системи цілей розвитку зовнішньоекономічної діяльності; вибір виду механізму розвитку зовнішньоекономічної діяльності; прийняття рішень 3 вибору методів досягнення встановлених цілей; створення умов для можливості застосування обраних методів для досягнення встановлених цілей; застосування методів досягнення цілей; аналізування стану досягнення встановлених цілей і коригування методів їх реалізації на основі зміни внутрішніх і зовнішніх умов розвитку зов- 


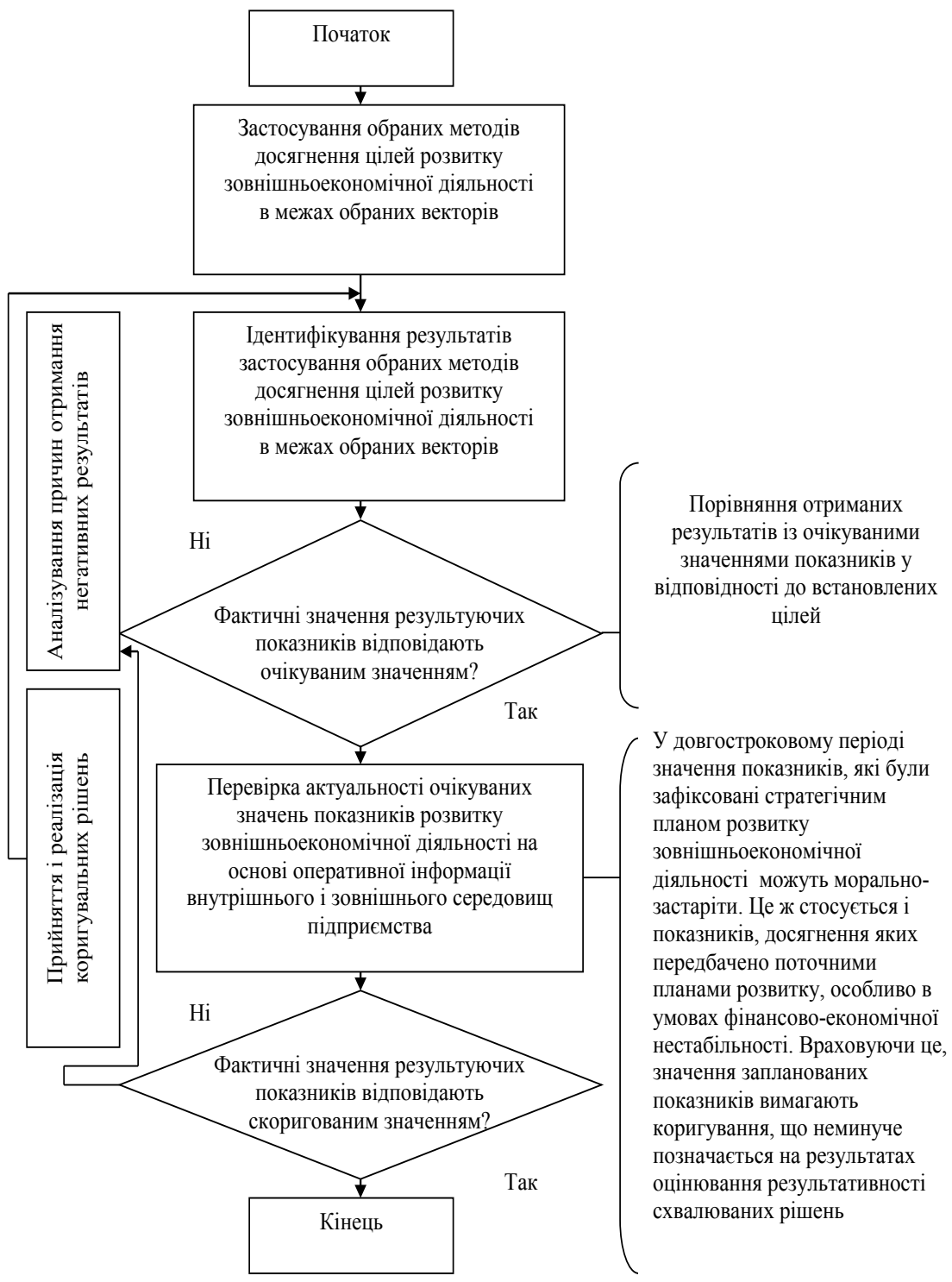

\section{Рис. 6. Етапи встановлення необхідності коригування методів реалізації цілей розвитку зовнішньоекономічної діяльності}




\section{Chapter «Economic sciences»}

нішньоекономічної діяльності промислового підприємства. Дотримання керівниками підприємств етапів вищенаведеної технології сприятиме раціоналізації управлінських рішень з розвитку зовнішньоекономічної діяльності підприємства.

\section{Список літератури:}

1. Шевців Л.Ю. Логістичні витрати підприємства: формування та оцінювання: монографія / Л.Ю. Шевців, І. Петецький. - Львів: Видавництво Львівської політехніки, 2011. - 244 с.

2. Торговельне підприємництво: механізми розвитку і фінансової підтримки: монографія / за наук. ред. д-ра екон. наук С.В. Князя. - Львів: Видавництво Львівської політехніки, 2015. - 724 с.

3. Князь С.В. Технологія формування механізмів зовнішньоекономічної діяльності підприємств / С.В. Князь, Н.Г. Георгіаді, І.О. Красілич // Науковий вісник Полісся. - 2017. - № 3(11), ч. 2. - С. 34-42.

4. Нагорна I. Транскордонне співробітництво як напрямок євроінтеграційних процесів в Україні / І. Нагорна // Теоретичні та прикладні питання державотворення. - К., 2007. - Вип. 2. - С. 6-10.

5. Сучасна регіональна політика і транскордонне співробітництво / В.І. Пила, О.С. Чмир, О.А. Гарасюк, Т.В. Терещенко. - Хмельницький: Видавництво ХУУП, 2006. - 412 с.

6. Герасимчук В., Шеламова I. Зниження енергоємності продукції ключовий фактор реалізації економічного потенціалу підприємств України [Електронний ресурс]. - Режим доступу: http://www.essuir.sumdu.edu.ua

\section{References:}

1. Shevtsiv L.Y. Lohistychni vytraty pidpryyemstva: formuvannya ta otsinyuvannya: monohrafiya / L.Y. Shevtsiv, I. Petetskyy. - Lviv: Vydavnytstvo Lvivskoyi politekhniky, 2011. - $244 \mathrm{~s}$.

2. Torhovelne pidpryyemnytstvo: mekhanizmy rozvytku i finansovoyi pidtrymky: monohrafiya / za nauk. red. d-ra ekon. nauk S.V. Knyazya. - Lviv: Vydavnytstvo Lvivskoyi politekhniky, 2015. - $724 \mathrm{~s}$.

3. Knyaz S.V. Tekhnolohiya formuvannya mekhanizmiv eksportno-importnoyi diyalnosti pidpryyemstv / S.V. Knyaz, N.H. Heorhiadi, I.O. Krasilych // Naukovyy visnyk Polissya. - 2017. - № 3(11), ch. 2. - S. 34-42.

4. Nahorna I. Transkordonne spivrobitnytstvo yak napryamok yevrointehratsiynykh protsesiv v Ukrayini / I. Nahorna // Teoretychni ta prykladni pytannya derzhavotvorennya. - K., 2007. - Vyp. 2. - S. 6-10.

5. Suchasna rehionalna polityka i transkordonne spivrobitnytstvo / V.I. Pyla, O.S. Chmyr, O.A. Harasyuk, T.V. Tereshchenko. - Khmelnytskyy: Vydavnytstvo KHUUP, 2006. $-412 \mathrm{~s}$.

6. Herasymchuk V., Shelamova I. Znyzhennya enerhoyemnosti produktsiyi - klyuchovyy faktor realizatsiyi ekonomichnoho potentsialu mashynobudivnykh pidpryyemstv Ukrayiny [Elektronnyy resurs]. - Rezhym dostupu: http://www.essuir.sumdu.edu.ua 